\title{
The relationship between labour unions' bargaining power and firms' operating flexibility: New evidence from emerging markets
}

\author{
I.G. Choi ${ }^{\mathrm{a}}$, P. Sohn ${ }^{\mathrm{b}}$ and J-Y Seo ${ }^{\mathrm{c*}}$ \\ ${ }^{a}$ Graduate student in Graduate School of Business Administration, Dong-A University, \\ 2-1, Bumin-dong, Seo-gu, Busan, 602-760, Republic of Korea \\ ${ }^{\mathrm{b}}$ Associate Professor in International Arbitration Department, Dong-A University, \\ 2-1, Bumin-dong, Seo-gu, Busan, 602-760, Republic of Korea \\ ${ }^{\mathrm{c}}$ Associate Professor in Department of Business Administration, Sangmyung University, \\ 20, Hongjimun 2-gil, Jongno-gu, Seoul, 110-743, Republic of Korea \\ *To whom all correspondence should be addressed \\ jyseo@smu.ac.kr
}

\begin{abstract}
This study analyses the relevance between the bargaining power of labour unions and the operating flexibility on firms' capital costs by using non-financial firms listed on the Korean stock exchange from 1999 to 2013. Under the assumption that constraints in business activities attributed to the collective bargaining power of labour unions lead to reduced operating flexibility and increased capital costs, we test this notion empirically; the main test results are as follows: First, we find from portfolio analysis that the cost of capital is higher for firms in more unionized industries. Second, we find that union coverage positively affects the cost of capital at a significant level. Third, we confirm through robustness tests that the industry adjusted union coverage (IAUC) also has a positive effect on the cost of capital at a significant level. As a result, the effect holds after controlling for a host of industry- and firm-level characteristics, and is stronger when unions have more favourable bargaining power. Thus, our findings are consistent with the hypothesis that the increase of labour unions' bargaining power leads to raise firms' capital costs by decreasing operating flexibility in the Korean firms.
\end{abstract}

\section{Introduction}

In this study, we try to approach the finance research issue: how the constraints of operating flexibility attributed to labour unions' bargaining power affect firms' cost of capital, with an empirical analysis. Although some researchers (Chen et al., 2011) have dealt with this issue in relation to U.S. firms, there are few studies on this topic that have used emerging market data due to difficulty of estimating operating flexibility. In this paper, we try to identify the main sources of operating flexibility, as well as its effect on capital cost, using variables related to labour unions' bargaining power.

However, like Danthine and Donaldson (2002), Gomes, Kogan and Zhang (2003), Merz and Yashiv (2007), previous studies have suggested that the operating flexibility of a firm significantly affects its cost of capital. Regarding this issue, we assume that there are important uncontrolled factors influencing the operating activities of firms due to the bargaining power of labour unions in the real business world. In terms of conceptual idea of finance theory, we conjecture that firms' operating flexibility may decrease if militant labour unions exist, leading to increases in systematic risk and firms' cost of equity.

Our assumption can be inferred as following examples. As a typical example of reducing operating flexibility in Korea, the Hyundai automobile company has been negatively affected by the bargaining power of labour unions in terms of operating performance, as rotation of night shift workers was abolished in 2012 with the increased incentives and wages. This example illustrates that labour unions' bargaining activity had a negative effect on operating flexibility of a famous Korean firm, the Hyundai automobile company.

\footnotetext{
1 This paper is a re-tested and revised manuscript with recent sample data based on the conceptual idea of the unpublished master's dissertation of Im Geun Choi (2013) at Dong-A University. We, authors, thank the first author, Im Geun Choi, for sharing his conceptual idea for the writing of this article. In addition, the authors wish to express their gratitude to the anonymous referees who provided valuable comments to improve the quality of this paper. This study was supported by research funds from Dong-A University. Professor Sohn and Professor Seo are corresponding author and co-author of this paper, respectively. Professor Sohn is responsible for the re-testing and revising of the unpublished dissertation of Choi, and Professor Seo turned the original draft in Korean into a completed manuscript in English, submitted the manuscript to the journal, and communicated with the journal's editor.
} 
In the light of above the Hyundai automobile case, we can draw out the assumptions in terms of two ways. First, the wage policy of a firm may lose flexibility depending on the collective bargaining activity of labour unions; for example, dismissal of employees may become more difficult, resulting in increased payroll costs. Thus, operating leverage will increase due to the activity of labour unions. Second, high costs are incurred in the adjustment of financial resources within firms because labour unions make firm restructuring, such as factory closures, more difficult. Thus, investors will require a high rate of return on investment capital due to firms' decreased operating flexibility.

This paper is in line with unpublished master's dissertation of Choi (2013), but we re-tested with more recent sample data. Thus, current study shows more robust findings with the latest trend in comparison with Choi (2013) analysing the relation between bargaining power of labour union of firms and operating flexibility in firm operation like manufacturing construction, manufacturing production line move, and even production time.

The remainder of this paper is organized as follows. In section 2, we review the results of theoretical backgrounds and set up the hypotheses. In section 3, we describe the empirical models. In section 4 , we provide the data collection and basic statistical methods, and in section 5, we show the test results. Finally, in section 6 , we provide conclusions.

\section{Theoretical backgrounds and hypotheses}

\section{Theoretical backgrounds}

As the research regarding operating leverage theme, there is the noteworthy research (Mandelker \& Rhee, 1984) suggesting that there is a positive relationship between the sensitivity of operating leverage and market beta representing market risk. In addition, we need to consider the research of Rosett (2001) on operating leverage related to the labour market suggests that market beta, representing the risk of equity, and volatility of stock return are positively related with labour costs paid to employees as the proxy variable for operating leverage under the constraints imposed by labour unions.

Another recent research (Gulen, Xing \& Zhang, 2011) shows that operating leverage has strong ability to predict the premium of value stock. In particular, the predictive power of operating leverage is very strong during a recession.

Meanwhile, Chen et al. (2011) shows that labour unions influence firms' operating activity, leading to increased equity cost. The more firms are included in a highly unionized industry or the stronger bargaining power of labour unions becomes, the stronger the effect of increasing equity costs attributed to labour unions will be. Finally, these researchers argued that reducing operating flexibility increases the cost of equity through counter-cyclicality.

\section{Hypotheses}

There are also the previous studies (Rubinstein, 1973; Lev, 1974; Booth, 1991) suggesting that total operating leverage has an effect on expected returns within the capital asset pricing (CAPM) model. However, the above mentioned study (Danthine \& Donaldson, 2002) asserted that the relationship between fixed labour costs and operating leverage is associated with the risk premium of equity, and that there is a significant relationship between operating leverage and systematic risk. Danthine and Donaldson (2002) argued that fixed labour costs are the main source of operating leverage, and they emerge from risk-sharing contract. Labour unions play a role in limiting the restructuring and closure of factories as the previous studies like Cooper (2006), Zhang (2005), Merz and Yashiv (2007) suggested. Thus, we assume that there is a positive relationship between the cost of capital and labour unions based on the above literatures. In the light of above reasoning and test results from previous studies, we set up the hypotheses below.

H1: The collective bargaining power of labour unions increases the cost of capital as a result of reducing operating flexibility.

Matsa (2010) argued that the collective bargaining power of labour unions within firms with high earning volatility has an effect on leverage. We can find research results from the previous study (Matsa, 2010) that used the general Nash equilibrium model to show that there is interaction between labour unions and earning volatility. From this result, we conjecture that investors view a firm as high risk if earnings volatility is high. Thus, investors will require high returns for high risk, a so-called risk premium, resulting in a high cost of equity for the firm. In terms of logical assumptions, we set up this hypothesis to be tested.

H2: The collective bargaining power of labour unions in negotiation with managers increases the cost of capital due to the increased earnings volatility ascribed to reduction of operations.

\section{Empirical models}

We consider firm- and industry-level data which are used for this verification. We adopt two testing methods to verify $\mathrm{H} 1$, which states that the collective 
bargaining power of labour unions increases the cost of capital due to a reduction in operating flexibility.

As the first testing method, we construct a five-tier portfolio based on union coverage. We calculate the cost of equity and cost of debt for each portfolio for estimation of the mean value. For reference, tier 1 is the group with the lowest union coverage, while tier 5 is the group with the highest union coverage. As the second testing method, we analyse the effect of collective bargaining power of labour unions on cost of equity to verify $\mathrm{H} 1$ and $\mathrm{H} 2$.

In equation (1) and (2), we use the market-to-book ratio (MB) as control variable, which is calculated by dividing the summed market value of equity and total debts by total assets. Beta is calculated by using daily data for 1 year based on the CAPM model. Leverage signifies leverage and is given by dividing total debts by total assets. Size refers to total assets and is estimated by adding a natural logarithm.

In addition, the ratio of earnings to industry adjusted earnings-price (IndEP) can be used as the proxy variable for capital costs according to the some studies (Francis, LaFond, Olsson \& Schipper, 2005). We calculate the IndEP by subtracting the median value of all firms' EP ratios from the EP ratios of firms within relevant industry at time $t$. We set up empirical models to confirm the relationship between the collective bargaining power of labour union and equity cost as follows.

$$
\begin{aligned}
\text { ECost }_{i, t} & =\alpha+\beta_{1} \text { UCoverage }_{i, t} \\
& +\beta_{2} \text { MB }_{i, t}+\beta_{3} \text { Leverage }_{i, t} \\
& +\beta_{4} \text { Beta }_{i, t}+\beta_{5} \text { Size }_{i, t}+e_{i, t} \\
\text { ECost }_{i, t} & =\alpha+\beta_{1} \text { UCoverage }_{i, t} \\
& +\beta_{2}\left(\text { UCoverage }_{\text {Volatility }}\right)_{i, t} \\
& +\beta_{3} \text { MB }_{i, t}+\beta_{4} \text { Leverage }_{i, t} \\
& +\beta_{5} \text { Beta }_{i, t}+\beta_{6} \text { Size }_{i, t}+e_{i, t}
\end{aligned}
$$

where

$\mathrm{ECost}=$ Equity Cost (IndEP)

$\mathrm{MB}=$ Market-to-Book Ratio

Leverage $=$ total debts/total assets

Beta=systematic risk for each firm

Size $=\ln$ (total assets)

UCoverage $=$ Union coverage of firm level or union coverage per industry

UCoverage $\cdot$ Volatility $=$ Interaction between labour union and earnings volatility

In equation (3) and (4), we consider the proxy variable of cost of debt which is used as the ratio of interest costs to average total debts. We also include control variables such as Leverage, size, return on assets
(ROA), interest coverage, earnings volatility, and so on in the empirical model in equations (3) and (4). Leverage indicates the ratio of total debts to total assets, and size is calculated by adding the natural logarithm. ROA is calculated as ratio net profit to total assets. IntCoverage signifies interest coverage, which represents the ratio of interest expense to operating profit. Volatility is calculated as the 3-year standard deviation of the ratio of operating cash flow to total assets. Interaction term between labour union coverage and volatility of earning is also included in the equation (3) and (4) like in the equation (1) and (2).

$$
\begin{aligned}
\text { DebtCost }_{i, t} & =\gamma_{0}+\gamma_{1} \text { UCoverage }_{i, t} \\
& +\gamma_{2} \text { Leverage }_{i, t}+\gamma_{3} \text { Size }_{i, t} \\
& +\gamma_{4} \text { ROA }_{i, t} \\
& +\gamma_{5} \text { IntCoverage }_{i, t}+e_{i, t} \\
\text { DebtCost }_{i, t} & =\gamma_{0}+\gamma_{1} \text { UCoverage }_{i, t} \\
& +\gamma_{2}\left(\text { UCoverage }_{\text {Volatility }}\right)_{i, t} \\
& +\gamma_{3} \text { Leverage }_{i, t}+\gamma_{4} \text { Size }_{i, t} \\
& +\gamma_{5} \text { ROA }_{i, t} \\
& +\gamma_{6} \text { IntCoverage }_{i, t} \\
& +\gamma_{7} \text { (Volatility }_{i, t}+e_{i, t}
\end{aligned}
$$

where

DebtCost $=$ Debt Cost

UCoverage $=$ Union coverage of firm level or union coverage per industry

UCoverage $\cdot$ Volatility $=$ Interaction between labour union and earnings volatility

\section{Data and basic statistics}

\section{Data}

We use sample data from 1999 to 2013 from Korean manufacturing firms listed on the Korean stock exchange. The data sources are FnGuide, a KisValue database, and Dart, a financial database of listed firms managed by the Korean financial supervisory service.

We select the final sample data through the following filtering procedures. First, we exclude firms with impairment of capital and workout firms. Second, we exclude financial firms. Third, we exclude firms that do not settle accounts in December from the final sample data. Fourth, we exclude firms with no data on labour. Fifth, we include sample firms even if sample firms has higher leverage ratio which is over $100 \%$ in leverage ratio, because this paper is not focused on the leverage issue. If we discard these firms in sample, the empirical results could be misread and provide a wrong understanding. Our sample data include 371 firms. Table 1 reports variable name and definition of variables used in this paper. 
Table 1: Definition of variables

\begin{tabular}{ll}
\hline Name & \multicolumn{1}{c}{ Definition } \\
\hline Equity Cost(ECost) & Earnings-Price Ratio with adjustment of industry \\
Debt Cost(DebtCost) & Interest expense $\div$ Total debts \\
Size & Ln(Total assets) \\
MB & (Market value of equity + Total debts) $\div$ total assets \\
Leverage & Total debts $\div$ Total assets \\
ROA & Net profit $\div$ Total assets \\
Volatility & 3-year standard deviation of (Operating cash flow $\div$ Total assets) \\
Beta & Estimated coefficient value for 1-year by using CAPM model \\
IntCoverage & Interest expense $\div$ Operating profit \\
\hline
\end{tabular}

\section{Basic statistics}

Table 2 shows the basic statistic on the variables used in this paper. The mean of union coverage is 0.495 , and a maximum value is 0.908 and a minimum value is 0.005 . Variation for union coverage of firms is wider and standard deviation of union coverage for each firm is 0.214 . The mean of industry adjusted union coverage (IAUC) is 2.492 and a maximum value is 4.848 and a minimum value is 0.585 .

Table 2: Basic statistic

\begin{tabular}{lccrr}
\hline Variables & Mean & $\begin{array}{c}\text { Standard } \\
\text { deviation }\end{array}$ & Min & Max \\
\hline UCoverage & 0.495 & 0.214 & 0.005 & 0.908 \\
IAUC & 2.492 & 1.384 & 0.585 & 4.848 \\
Debt Cost & 0.049 & 0.038 & 0.000 & 0.351 \\
ECost & -0.339 & 6.462 & -149.061 & 100.833 \\
Leverage & 0.516 & 0.238 & 0.057 & 2.797 \\
Tangibility & 0.591 & 0.163 & 0.108 & 0.929 \\
Size & 19.416 & 1.461 & 15.924 & 24.006 \\
ROA & 0.034 & 0.127 & -0.989 & 1.394 \\
MB & 0.861 & 0.384 & 0.205 & 4.717 \\
IntCoverage & 11.59 & 35.72 & -345.33 & 1344.94 \\
Beta & 0.635 & 0.327 & -0.163 & 1.999 \\
Volatility & 0.039 & 0.034 & 0.000 & 3.364 \\
\hline
\end{tabular}

Table 3 presents union coverage for each industry. The highest union coverage is in the transportation equipment industry, with a mean of $64.2 \%$. Next is paper and wood. Finally, the lowest union coverage is in medicine with $25.9 \%$.

Table 3: Union coverage for each industry

\begin{tabular}{lcc}
\hline Industry & Mean & Median \\
\hline Medicine & 0.259 & 0.234 \\
Food and beverage & 0.346 & 0.284 \\
Textile and clothing & 0.421 & 0.398 \\
Chemistry & 0.491 & 0.482 \\
Transportation equipment & 0.642 & 0.676 \\
Machinery & 0.516 & 0.547 \\
Nonmetallic mineral & 0.513 & 0.497 \\
Electrical and electronics & 0.526 & 0.564 \\
Manufacturing & 0.545 & 0.568 \\
Steel and metal & 0.587 & 0.599 \\
Paper and wood & 0.629 & 0.657 \\
Others & 0.498 & 0.575 \\
\hline
\end{tabular}

(Notice) Industry is classified by Korean standard industrial classification (KSIC) at 9th and KSE

\section{Empirical Results}

Table 4 shows that the mean and median of industryadjusted equity costs are -0.784 and -0.746 in portfolio 1 , respectively with the weakest bargaining power. Table 4 also shows that the mean and median of industry-adjusted equity costs are 0.348 and 0.231 in portfolio 5, which has the strongest bargaining power, respectively. Thus, we see a pattern of increasing industry-adjusted equity costs as moving from portfolio 1 to portfolio 5 . 
Meanwhile, a significant difference at the $1 \%$ level in the mean and median can be observed through the ttest and median score test between portfolio 1 and portfolio 5. Thus, the mean and median of cost of debt in portfolio 1 are $4.2 \%$ and $3.9 \%$, respectively. Like cost of equity, we also find a pattern of increasing industry-adjusted debt cost from portfolio 1 to portfolio 5 .
Additionally, we observe a significant difference in the mean and median between portfolio 1 and portfolio 5 through the t-test and median score test. Thus, we find that the lower the cost of equity and cost of debt are, the weaker collective bargaining power of labour union becomes, and vice versa.

\section{Table 4: The results over portfolios}

\begin{tabular}{lcccccc}
\hline & & & & & t-test, & $\begin{array}{c}\text { Tht } \\
\text { Median Score Test }\end{array}$ \\
\hline UCoverage Mean & $\mathbf{1}($ Low $)$ & $\mathbf{2}$ & $\mathbf{3}$ & $\mathbf{4}$ & $\mathbf{5}($ High) & \\
& 0.165 & 0.387 & 0.519 & 0.634 & 0.749 & \\
ECost Mean & $(0.191)$ & $(0.392)$ & $(0.523)$ & $(0.636)$ & $(0.739)$ & \\
& -0.784 & -0.679 & -0.175 & -0.329 & 0.348 & $8.98 * * *$ \\
Debt Cost Mean & $(-0.746)$ & $(-0.638)$ & $(-0.171)$ & $(-0.314)$ & $(0.231)$ & $7.57 * * *$ \\
& 0.042 & 0.046 & 0.049 & 0.045 & 0.057 & $3.29 * * *$ \\
& $(0.039)$ & $(0.034)$ & $(0.039)$ & $(0.046)$ & $(0.051)$ & $2.78^{* * *}$ \\
\hline
\end{tabular}

(Notice) $* * *$ is significant at $1 \%$. ( ) denotes median

We use the regression method to confirm $\mathrm{H} 1$ and $\mathrm{H} 2$ because portfolio analysis does not include control variables.

Table 5 shows the test results for the verification of $\mathrm{H} 1$, which states that the collective bargaining power of labour unions increases the cost of debt due to a reduction in operating flexibility. In Model 1 and Model 2, using pooled ordinary least squares (OLS) without control variables, we find t-values of 4.06 and 3.39 with a $1 \%$ significance level after including union coverage.
Meanwhile, all coefficients of union coverage in Model 1 and Model 2 are positive at $1 \%$ significance level. Thus, we infer that the cost of debt is increased due to the reduced operating flexibility ascribed to the strong collective bargaining power of labour unions. In addition, we find positive coefficient values of union coverage at the $1 \%$ significance level based on fixed-effects models like Model 1 and Model 2.

Table 5: Test results on hypothesis 1 for debt cost by using union coverage

\begin{tabular}{|c|c|c|c|c|}
\hline & \multicolumn{2}{|c|}{ Pooled OLS } & \multicolumn{2}{|c|}{ Fixed Effect Model } \\
\hline & Model 1 & Model 2 & Model 3 & Model 4 \\
\hline \multirow[t]{2}{*}{ Intercept } & $0.0536 * * *$ & -0.0024 & $0.0621 * * *$ & $0.4292 * * *$ \\
\hline & (19.02) & $(-0.25)$ & $(23.91) * * *$ & $(6.08)$ \\
\hline \multirow[t]{2}{*}{ UCoverage } & $0.0089 * * *$ & $0.0068 * * *$ & $0.0361 * * *$ & $0.052 * * *$ \\
\hline & $(4.06)$ & $(3.39)$ & (3.34) & $(3.45)$ \\
\hline \multirow[t]{2}{*}{ Leverage } & & $1.7334 * * *$ & & $0.0542 * * *$ \\
\hline & & (21.04) & & (13.67) \\
\hline \multirow[t]{2}{*}{ Size } & & $-0.7896 * * *$ & & $-0.0192 * * *$ \\
\hline & & $(12.49)$ & & $(-6.09)$ \\
\hline \multirow[t]{2}{*}{ ROA } & & -0.0039 & & $0.0229 * * *$ \\
\hline & & $(-1.16)$ & & $(4.03)$ \\
\hline \multirow[t]{2}{*}{ IntCoverage } & & 0.0000 & & 0.0000 \\
\hline & & $(-1.48)$ & & $(0.82)$ \\
\hline Time Effect & & & Yes & Yes \\
\hline Firm Effect & & & Yes & Yes \\
\hline Industry Effect & Yes & Yes & Yes & Yes \\
\hline Adj. $\mathrm{R}^{2}$ & 0.035 & 0.307 & 0.047 & 0.502 \\
\hline F-Value & $27.59 * * *$ & $106.94 * * *$ & $11.85^{* * *}$ & $45.59 * * *$ \\
\hline
\end{tabular}

Table 6 provides evidence to verify $\mathrm{H} 1$ in terms of cost of equity. First of all, we find that the coefficient values of union coverage in all models regardless of kinds of analysis models are positively significant. Thus, we confirm that $\mathrm{H} 1$ is accepted. 
Table 6: Test results on hypothesis 1 for equity cost by using union coverage

\begin{tabular}{|c|c|c|c|c|c|c|c|c|}
\hline & \multicolumn{4}{|c|}{ Pooled OLS } & \multicolumn{4}{|c|}{ Fixed Effect Model } \\
\hline & \multicolumn{2}{|l|}{ Model 1} & \multicolumn{2}{|c|}{ Model 2} & \multicolumn{2}{|c|}{ Model 3} & \multicolumn{2}{|c|}{ Model 4} \\
\hline \multirow[t]{2}{*}{ Intercept } & 0.1351 & & 6.9338 & $* * *$ & -3.2491 & $* *$ & 28.5685 & $* * *$ \\
\hline & $(0.34)$ & & $(2.74)$ & & $(-3.08)$ & & (17.67) & \\
\hline \multirow[t]{2}{*}{ UCoverage } & 0.9938 & $* *$ & 0.4831 & $* *$ & 6.0428 & $* *$ & 5.0462 & $* *$ \\
\hline & $(2.36)$ & & $(2.46)$ & & $(2.24)$ & & $(2.04)$ & \\
\hline \multirow[t]{2}{*}{ MB } & & & -0.6067 & & & & -0.5172 & \\
\hline & & & $(-1.27)$ & & & & $(-0.87)$ & \\
\hline \multirow[t]{2}{*}{ Leverage } & & & -5.7451 & $* * *$ & & & -12.8461 & $* * *$ \\
\hline & & & $(-7.69)$ & & & & $(-11.58)$ & \\
\hline \multirow[t]{2}{*}{ Beta } & & & 0.9849 & & & & 0.0434 & \\
\hline & & & (1.37) & & & & $(0.18)$ & \\
\hline \multirow[t]{2}{*}{ Size } & & & -0.2242 & $*$ & & & -1.8437 & $*$ \\
\hline & & & $(-1.79)$ & & & & $(-1.64)$ & \\
\hline Time Effect & & & & & Yes & & Yes & \\
\hline Firm Effect & & & & & Yes & & Yes & \\
\hline Industry Effect & Yes & & Yes & & Yes & & Yes & \\
\hline Adj. $R^{2}$ & 0.034 & & 0.169 & & 0.015 & & 0.0257 & \\
\hline F-Value & 4.65 & $* * *$ & 17.84 & $* * *$ & 5.69 & $* * *$ & 30.09 & $* * *$ \\
\hline
\end{tabular}

Adopted the pooled OLS approach and fixed-effects models, test results in Table 7 presents the verification results for $\mathrm{H} 2$, which states that the collective bargaining power of labour unions in negotiation with managers increases the cost of debt due to the increasing earnings volatility ascribed to reduced operations.

We find support for $\mathrm{H} 2$, as the coefficient values of the interaction term between union coverage and earnings volatility in Model 1 and Model 2 are positively significant at the $1 \%$ level, regardless of whether control variables are included. Through Model 3 and Model 4, based on the fixed-effects models, we also find a positively significant coefficient value of interaction terms, as in Model 1 and Model 2.

Therefore, these results are line with the previous study (Matsa, 2010) suggesting evidence based on the general Nash equilibrium that there is interaction between labour unions and earnings volatility.

Table 7: Test results on hypothesis 2 for debt cost by using union coverage

\begin{tabular}{|c|c|c|c|c|c|c|c|c|}
\hline \multirow[b]{3}{*}{ Intercept } & \multicolumn{4}{|c|}{ Pooled OLS } & \multicolumn{4}{|c|}{ Fixed Effect Model } \\
\hline & \multicolumn{2}{|c|}{ Model 1} & \multicolumn{2}{|l|}{ Model 2} & \multicolumn{2}{|c|}{ Model 3} & \multicolumn{2}{|l|}{ Model 4} \\
\hline & $\begin{array}{c}0.0539 \\
(19.74)\end{array}$ & $* * *$ & $\begin{array}{r}0.0104 \\
(0.43)\end{array}$ & & $\begin{array}{r}0.0381 \\
(8.38)\end{array}$ & $* * *$ & $\begin{array}{r}0.4558 \\
(6.95)\end{array}$ & $* * *$ \\
\hline UCoverage & $\begin{array}{r}0.0503 \\
(5.34)\end{array}$ & $* * *$ & $\begin{array}{r}0.0408 \\
(4.81)\end{array}$ & $* * *$ & $\begin{array}{r}0.0513 \\
(3.08)\end{array}$ & $* * *$ & $\begin{array}{r}0.0617 \\
(2.95)\end{array}$ & $* *$ \\
\hline (UCoverage $\cdot$ Volatility) & $\begin{array}{r}0.1237 \\
(4.29)\end{array}$ & $* * *$ & $\begin{array}{r}0.0209 \\
(3.21)\end{array}$ & $* * *$ & $\begin{array}{r}0.2084 \\
(3.92)\end{array}$ & $* * *$ & $\begin{array}{r}0.0704 \\
(3.03)\end{array}$ & $* * *$ \\
\hline Leverage & & & $\begin{array}{r}0.0746 \\
(22.84)\end{array}$ & $* * *$ & & & $\begin{array}{r}0.0634 \\
(13.92)\end{array}$ & $* * *$ \\
\hline Size & & & $\begin{array}{r}0.8367 \\
(9.29)\end{array}$ & $* * *$ & & & $\begin{array}{r}-0.0295 \\
(-6.04)\end{array}$ & $* * *$ \\
\hline ROA & & & $\begin{array}{r}-0.0072 \\
(-0.94)\end{array}$ & & & & $\begin{array}{r}0.0208 \\
(3.15)\end{array}$ & $* * *$ \\
\hline IntCoverage & & & $\begin{array}{r}0.0000 \\
(0.39)\end{array}$ & & & & $\begin{array}{r}0.0000 \\
(0.46)\end{array}$ & \\
\hline Volatility & & & $\begin{array}{r}-0.0789 \\
(-1.98)\end{array}$ & $* *$ & & & $\begin{array}{r}0.0241 \\
(0.29)\end{array}$ & \\
\hline Time Effect & & & & & Yes & & Yes & \\
\hline Firm Effect & & & & & Yes & & Yes & \\
\hline Industry Effect & Yes & & Yes & & Yes & & Yes & \\
\hline Adj. $\mathrm{R}^{2}$ & 0.040 & & 0.284 & & 0.084 & & 0.503 & \\
\hline F-Value & 3.78 & $* * *$ & 5.87 & $* * *$ & 10.59 & $* * *$ & 29.97 & $* * *$ \\
\hline
\end{tabular}


Regardless of model type, Table 8 shows that the coefficient value and interaction term between union coverage and earnings volatility is positively significant. Thus, all interaction term in all models are significant at the $1 \%$ level.

In addition, we find negatively significant coefficient values such as size and interest coverage in Model 2 and Model 4, which includes control variables.
In the light of above test results, we support those of the previous study (Matsa, 2010) arguing that interaction between labour unions and earnings volatility reduces operating flexibility, resulting in increased equity cost.

Table 8: Test results on hypothesis 2 for equity cost by using union coverage

\begin{tabular}{|c|c|c|c|c|c|c|c|c|}
\hline & \multicolumn{4}{|c|}{ Pooled OLS } & \multicolumn{4}{|c|}{ Fixed Effect Model } \\
\hline & Model 1 & & Model 2 & & Model 3 & & Model 4 & \\
\hline Intercept & $\begin{array}{r}0.1829 \\
(0.48)\end{array}$ & & $\begin{array}{r}6.2874 \\
(3.32)\end{array}$ & $* *$ & $\begin{array}{r}-4.0420 \\
(-3.47)\end{array}$ & $* *$ & $\begin{array}{r}23.6524 \\
(1.41)\end{array}$ & \\
\hline UCoverage & $\begin{array}{r}0.7563 \\
(2.09)\end{array}$ & $* *$ & $\begin{array}{r}2.8138 \\
(3.02)\end{array}$ & $* *$ & $\begin{array}{r}6.2151 \\
(1.98)\end{array}$ & $* *$ & $\begin{array}{r}7.7608 \\
(2.78)\end{array}$ & $* * *$ \\
\hline (UCoverage $\cdot$ Volatility) & $\begin{array}{r}8.9325 \\
(4.92)\end{array}$ & $* * *$ & $\begin{array}{r}8.1784 \\
(4.09)\end{array}$ & $* * *$ & $\begin{array}{r}6.2716 \\
(4.09)\end{array}$ & $* * *$ & $\begin{array}{r}7.6065 \\
(2.69)\end{array}$ & $* * *$ \\
\hline Leverage & & & $\begin{array}{r}-0.7662 \\
(-1.57)\end{array}$ & & & & $\begin{array}{r}-0.5239 \\
(-0.73)\end{array}$ & \\
\hline Size & & & $\begin{array}{r}-5.9845 \\
(-8.01)\end{array}$ & $* * *$ & & & $\begin{array}{r}-12.0683 \\
(-10.88)\end{array}$ & $* * *$ \\
\hline ROA & & & $\begin{array}{r}1.6216 \\
(1.72)\end{array}$ & $*$ & & & $\begin{array}{r}0.0219 \\
(0.03)\end{array}$ & \\
\hline IntCoverage & & & $\begin{array}{r}-0.2283 \\
(-1.49)\end{array}$ & & & & $\begin{array}{r}-1.1209 \\
(-1.30)\end{array}$ & \\
\hline Volatility & & & $\begin{array}{r}4.2742 \\
(4.92)\end{array}$ & $* * *$ & & & $\begin{array}{r}5.7469 \\
(4.12)\end{array}$ & $* * *$ \\
\hline Time Effect & & & & & Yes & & Yes & \\
\hline Firm Effect & & & & & Yes & & Yes & \\
\hline Industry Effect & Yes & & Yes & & Yes & & Yes & \\
\hline Adj. $\mathrm{R}^{2}$ & 0.008 & & 0.059 & & 0.003 & & 0.051 & \\
\hline F-Value & 12.83 & $* * *$ & 18.24 & $* * *$ & 12.97 & $* * *$ & 23.38 & $* * *$ \\
\hline
\end{tabular}

As the robustness test, we try to reconfirm the acceptance of the hypotheses through the regression method using another proxy variable representing the collective bargaining power of labour unions rather than union coverage. Thus, we develop and adopt industry adjusted union coverage measure (IAUC) as the proxy for the collective bargaining power of labour union based on industry adjusted measure.

The following equation measures the Industry Union Concentration Index (IAUC) as new measure of collective bargaining power of labour union. In this equation (5) and (6), CCost indicates debt cost and equity cost. Using IAUC, we set up the empirical models as follows.

$$
\begin{aligned}
\text { CCost }_{i, t} & =\alpha+\beta_{1} \text { IAUC }_{i, t} \\
& +\sum_{i=1}^{N} \gamma_{i} \text { ControlV }_{i, t}+e_{i, t}
\end{aligned}
$$

$$
\begin{aligned}
\text { CCost }_{i, t} & =\alpha+\beta_{1} \text { IAUC }_{i, t} \\
& +\beta_{2}\left(\text { IAUC } \cdot{\text { Volatility })_{i, t}}^{N}\right. \\
& +\sum_{i=1}^{N} \gamma_{i} \text { Controlv }_{i, t}+e_{i, t}
\end{aligned}
$$

Industry adjusted union coverage (IAUC) $=\sum_{i=1}^{N}\left[\text { Union }_{i, j, t}-E(\text { Union })_{j, t}\right]^{2}$

Industry adjusted union coverage (IAUC) $=\sum_{i=1}^{N}\left[\text { Union }_{i, j, t}-E(\text { Union })_{j, t}\right]^{2}$

$$
\begin{aligned}
& E(\text { Union })_{j, t} \\
& =\text { average ratio of union member in } j \\
& \text { industry at time } t
\end{aligned}
$$




\section{Union $_{i, j, t}$ \\ $=$ ratio of union member in $i$ firm within $j$ industry at time $t$}

Table 9 is the verification result for $\mathrm{H} 1$ regarding cost of debt using IAUC instead of union coverage, and may be compared with Table 5 .
Regardless of the type of model, we find that all coefficient values of IAUC are positively significant, and confirm the robustness of the results in $\langle$ Table 5>. All coefficient values of leverage are positively significant at the $1 \%$ level.

Table 9: Test results on hypothesis 1 for debt cost by using IAUC

\begin{tabular}{|c|c|c|c|c|c|c|c|c|}
\hline \multirow{3}{*}{ Intercept } & \multicolumn{4}{|c|}{ Pooled OLS } & \multicolumn{4}{|c|}{ Fixed Effect Model } \\
\hline & \multicolumn{2}{|c|}{ Model 1} & \multicolumn{2}{|c|}{ Model 2} & \multicolumn{2}{|c|}{ Model 3} & \multicolumn{2}{|c|}{ Model 4} \\
\hline & 0.0635 & $* * *$ & -0.0027 & & 0.0676 & $* * *$ & 0.5131 & $* * *$ \\
\hline & $(29.49)$ & & $(-0.27)$ & & $(9.94)$ & & $(7.05)$ & \\
\hline \multirow[t]{2}{*}{ IAUC } & 0.0026 & $* * *$ & 0.0036 & $* *$ & 0.0087 & $* * *$ & 0.0012 & $* *$ \\
\hline & $(4.01)$ & & $(3.03)$ & & $(2.82)$ & & $(2.34)$ & \\
\hline \multirow[t]{2}{*}{ Leverage } & & & 0.0746 & $* * *$ & & & 0.0728 & $* * *$ \\
\hline & & & $(22.62)$ & & & & $(13.83)$ & \\
\hline \multirow[t]{2}{*}{ Size } & & & 0.0034 & $* *$ & & & -0.0284 & $* * *$ \\
\hline & & & $(1.96)$ & & & & $(-7.08)$ & \\
\hline \multirow[t]{2}{*}{ ROA } & & & -0.0094 & & & & 0.0225 & $* * *$ \\
\hline & & & $(-1.32)$ & & & & (3.69) & \\
\hline \multirow[t]{2}{*}{ IntCoverage } & & & 0.0000 & & & & 0.0000 & \\
\hline & & & $(0.97)$ & & & & $(0.28)$ & \\
\hline Time Effect & & & & & Yes & & Yes & \\
\hline Firm Effect & & & & & Yes & & Yes & \\
\hline Industry Effect & Yes & & Yes & & Yes & & Yes & \\
\hline Adj. $R^{2}$ & 0.092 & & 0.298 & & 0.097 & & 0.413 & \\
\hline F-Value & 14.28 & $* * *$ & 12.54 & $* * *$ & 10.38 & $* * *$ & 39.69 & $* * *$ \\
\hline
\end{tabular}

(Notice) $* * *, * *$, and $*$ are significant $1 \%, 5 \%$, and $10 \%$, respectively

Table 10 gives the verification result for $\mathrm{H} 1$ regarding cost of equity including IAUC instead of union coverage, and may be compared with Table 6 . In all models, the coefficient values of IAUC are positively significant at the $5 \%$ level. This result is line with the results in Table 6 . We also find negatively significant coefficient values, such as Leverage and size, in Model 3 and Model 4, which includes control variables. These results are the same as those in Model 3 and Model 4 in Table 6; this evidence strongly supports $\mathrm{H} 1$.

Table 10: Test results on hypothesis 1 for equity cost by using IAUC

\begin{tabular}{|c|c|c|c|c|c|c|c|c|}
\hline \multirow{3}{*}{ Intercept } & \multicolumn{4}{|c|}{ Pooled OLS } & \multicolumn{4}{|c|}{ Fixed Effect Model } \\
\hline & \multicolumn{2}{|l|}{ Model 1} & \multicolumn{2}{|c|}{ Model 2} & \multicolumn{2}{|c|}{ Model 3} & \multicolumn{2}{|c|}{ Model 4} \\
\hline & -0.3274 & & 6.9162 & $* * *$ & -0.2065 & & 0.3437 & $* *$ \\
\hline & $(-0.94)$ & & $(2.71)$ & & $(-0.48)$ & & $(2.04)$ & \\
\hline \multirow[t]{2}{*}{ IAUC } & 0.0291 & $* *$ & 0.0279 & $* *$ & 0.2673 & $* *$ & 0.0873 & $* *$ \\
\hline & $(2.22)$ & & $(2.34)$ & & $(2.37)$ & & $(2.39)$ & \\
\hline \multirow[t]{2}{*}{ MB } & & & -0.5351 & & & & -0.6862 & \\
\hline & & & $(-0.99)$ & & & & $(-0.92)$ & \\
\hline \multirow[t]{2}{*}{ Leverage } & & & -5.4892 & $* * *$ & & & -12.5746 & $* * *$ \\
\hline & & & $(-8.39)$ & & & & $(-11.17)$ & \\
\hline \multirow[t]{2}{*}{ Beta } & & & 1.2461 & $*$ & & & 0.0412 & \\
\hline & & & $(1.72)$ & & & & $(0.06)$ & \\
\hline \multirow[t]{2}{*}{ Size } & & & -0.3056 & $*$ & & & -1.2568 & $* *$ \\
\hline & & & $(-1.74)$ & & & & $(-2.42)$ & \\
\hline Time Effect & & & & & Yes & & Yes & \\
\hline Firm Effect & & & & & Yes & & Yes & \\
\hline Industry Effect & Yes & & Yes & & Yes & & Yes & \\
\hline Adj. $\mathrm{R}^{2}$ & 0.002 & & 0.067 & & 0.004 & & 0.067 & \\
\hline F-Value & 0.33 & & 17.42 & $* * *$ & 0.38 & & 29.02 & $* * *$ \\
\hline
\end{tabular}

Table 11 gives the verification result for $\mathrm{H} 2$ regarding cost of debt including IAUC instead of union coverage, and may be compared with Table 7 . In all models, the coefficient values of the IAUC and the 
interaction term between IAUC and earnings volatility are positively significant. In particular, the coefficient values of $0.0078,0.0029,0.0051$, and 0.0006 of the IAUC in Model 1, Model 2, Model 3, and Model 4 respectively, are significant at the $1 \%$ and $5 \%$ level. This result is consistent with the result found in Table
7. For the interaction term, the coefficient value in Model 1, Model 2, Model 3, and Model 4 is significant at the $1 \%$ and $5 \%$ level. Therefore, we strongly reconfirm the acceptance of $\mathrm{H} 1$ and $\mathrm{H} 2$ regarding cost of debt.

Table 11: Test results on hypothesis 2 for debt cost by using IAUC

\begin{tabular}{|c|c|c|c|c|c|c|c|c|}
\hline \multirow{3}{*}{ Intercept } & \multicolumn{4}{|c|}{ Pooled OLS } & \multicolumn{4}{|c|}{ Fixed Effect Model } \\
\hline & \multicolumn{2}{|c|}{ Model 1} & \multicolumn{2}{|c|}{ Model 2} & \multicolumn{2}{|c|}{ Model 3} & \multicolumn{2}{|c|}{ Model 4} \\
\hline & $\begin{array}{c}0.0509 \\
(25.48)\end{array}$ & $* * *$ & $\begin{array}{l}0.0204 \\
(2.19)\end{array}$ & $* * *$ & $\begin{array}{l}0.0664 \\
(9.59)\end{array}$ & $* * *$ & $\begin{array}{l}0.4091 \\
(6.32)\end{array}$ & $* * *$ \\
\hline IAUC & $\begin{array}{l}0.0078 \\
(4.04)\end{array}$ & $* * *$ & $\begin{array}{l}0.0029 \\
(3.17)\end{array}$ & $* * *$ & $\begin{array}{l}0.0051 \\
(3.06)\end{array}$ & $* * *$ & $\begin{array}{l}0.0006 \\
(2.29)\end{array}$ & $* *$ \\
\hline (IAUC·Volatility) & $\begin{array}{l}0.1673 \\
(2.89)\end{array}$ & $* * *$ & $\begin{array}{l}0.0762 \\
(2.58)\end{array}$ & $* *$ & $\begin{array}{l}0.2282 \\
(2.89)\end{array}$ & $* *$ & $\begin{array}{l}0.1759 \\
(2.25)\end{array}$ & $* *$ \\
\hline Leverage & & & $\begin{array}{c}0.0758 \\
(21.67)\end{array}$ & $* * *$ & & & $\begin{array}{c}0.0594 \\
(12.83)\end{array}$ & $* * *$ \\
\hline Size & & & $\begin{array}{l}-0.0009 \\
(-2.26)\end{array}$ & $* *$ & & & $\begin{array}{l}-0.0247 \\
(-6.04)\end{array}$ & $* * *$ \\
\hline $\mathrm{ROA}$ & & & $\begin{array}{l}0.0327 \\
(4.24)\end{array}$ & $* * *$ & & & $\begin{array}{l}0.0296 \\
(3.04)\end{array}$ & $* * *$ \\
\hline IntCoverage & & & $\begin{array}{l}0.0000 \\
(0.79)\end{array}$ & & & & $\begin{array}{l}0.0000 \\
(0.41)\end{array}$ & \\
\hline Volatility & & & $\begin{array}{l}-0.0305 \\
(-0.99)\end{array}$ & & & & $\begin{array}{l}0.0424 \\
(2.09)\end{array}$ & $* *$ \\
\hline Time Effect & & & & & Yes & & Yes & \\
\hline Firm Effect & & & & & Yes & & Yes & \\
\hline Industry Effect & Yes & & Yes & & Yes & & Yes & \\
\hline Adj. $\mathrm{R}^{2}$ & 0.016 & & 0.301 & & 0.023 & & 0.481 & \\
\hline F-Value & 11.45 & $* * *$ & 74.93 & $* * *$ & 3.84 & $* *$ & 4.09 & $* * *$ \\
\hline
\end{tabular}

Table 12 provides the verification result for $\mathrm{H} 2$ regarding cost of equity, including IAUC instead of union coverage, and may be compared with Table 8 . In all models, the coefficient values of IAUC and the interaction term between IAUC and volatility from cash flow are positively significant, as in Table 8 . In particular, the coefficient values, 0.0249, 0.0603, 0.1279 , and 0.7614 of the IAUC from Model 1, Model 2, Model 3, and Model 4 are significant at the $1 \%$ and $5 \%$ level. In addition, the coefficient values of the interaction term are significant at the 5\% level compared with those of the interaction term with a $1 \%$ significance level regardless of model specifications in Table 8 . Therefore, we reconfirm the acceptance of $\mathrm{H} 2$.

\section{Conclusion}

This study examined whether the collective bargaining power of labour unions reduces operating flexibility, resulting in increased capital costs. The main findings in this study were as follows. First, through a five-portfolio analysis, we provided evidence that when labour unions have strong bargaining power, firms have higher capital costs than that when labour unions' bargaining power is weaker. Second, we were able to confirm that union coverage has a positive effect on cost of capital at a significant level. However, this effect is stronger in terms of cost of debt than cost of equity. Third, we reconfirmed the evidence from our regression estimations via robustness testing using the IAUC. Thus, it was shown that the IAUC positively affects the cost of capital through interaction between IAUC and earnings volatility. As a result, we can suggest that collective bargaining power plays a pivotal role in determining the cost of capital, leading to increased capital costs as shown in previous studies. 
Table 12: Test results on hypothesis 2 for equity cost by using IAUC

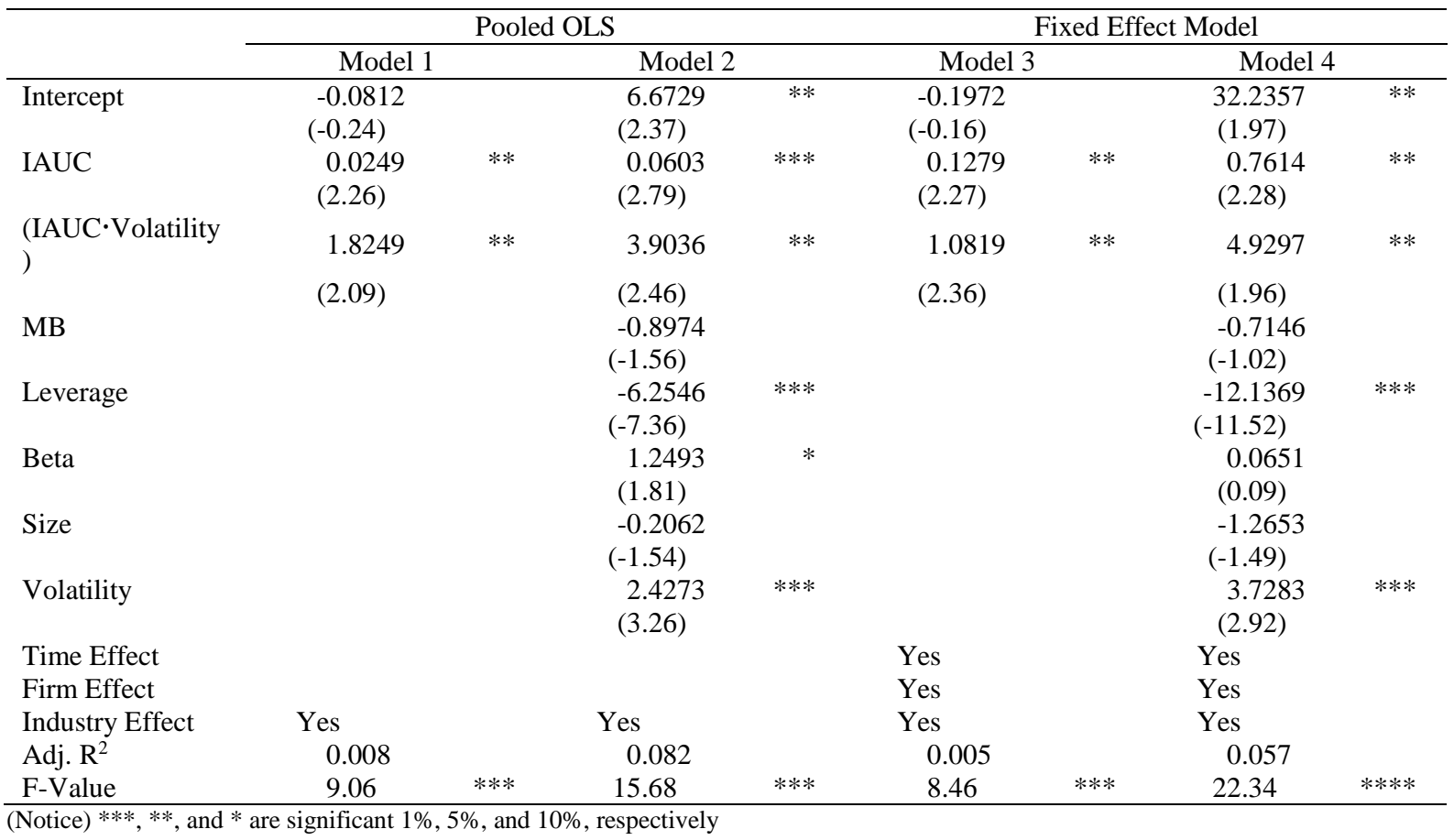

As the research contributions, current study used various proxy variables representing the collective bargaining power of labour unions, such as union coverage and the IAUC, based on multiple estimation methods, namely portfolio analysis and two types of regression estimation. In addition, this study analysed the emerging market data to find out whether operating flexibility affects the cost of capital unlike the previous studies that using U.S. firm data. Due to this different approach in terms of methodology and sample data, we think that our study fills a gap left by previous research and will contribute to developing this issue in the field of corporate finance.

\section{References}

Booth, L. 1991. 'The influence of production technology on risk and the cost of capital', Journal of Financial and Quantitative Analysis, 26(1): 109-127.

Chen, H. J, Kacperczyk, M. \& Ortiz-Molina, H. 2011, 'Labor unions, operating flexibility, and the cost of equity', Journal of Financial and Quantitative Analysis, 46(1): 25-58.

Choi, I. G. 2013, 'How do collective bargaining powers of labor unions affect operating flexibility and cost of capital?', Master's Dissertation in Dong-A University, Not Published:1-27.

Cooper, I. 2006. 'Asset pricing implications of nonconvex adjustment costs and irreversibility of investment', Journal of Finance, 61(1): 139-170.
Danthine, J.-P. \& Donaldson, J. B. 2002. 'Labour relations and asset returns', Review of Economic Studies, 69(1): 41-64.

Francis, J., LaFond, R., Olsson, P. \& Schipper, K. 2005. 'The market pricing of accruals quality', Journal of Accounting and Economics, 39(2): 295327.

Gomes, J., Kogan, L. \& Zhang, L. 2003. 'Equilibrium cross section of returns', Journal of Political Economy, 111(4): 693-732.

Gulen, H., Xing, Y. \& Zhang, L. 2011. 'Value versus growth: time-varying expected stock returns', Financial Management, 40(2): 381-407.

Lev, B. 1974. 'On the association between operating leverage and risk', Journal of Financial and Quantitative Analysis, 9(4): 627-641.

Mandelker, G. N. \& Rhee, S. G. 1984. 'The impact of the degrees of operating and financial leverage on systematic risk of common stock', Journal of Financial and Quantitative Analysis, 19(1): 45-57.

Matsa, D. A. 2010. 'Capital structure as a strategic variable: evidence from collective bargaining', Journal of Finance, 65(3): 1197-1232.

Merz, M. \& Yashiv, E. 2007. 'Labour and the market value of the firm', American Economic Review, 97(4): 1419-1431. 
Rosett, J. G. 2001. 'Equity risk and the labour stock: the case of union contracts', Journal of Accounting Research, 39(2): 337-364.

Rubinstein, M. E. 1973. 'A mean-variance synthesis of corporate financial theory', Journal of Finance, 28(1): 167-181.

Zhang, L. 2005. 'The value premium', Journal of Finance, 60(1): 67-103. 
